\title{
The Impact of Personal Characteristics on Innovative Work Behaviour: An Exploration into Innovation and Its Determinants amongst Teachers
}

\author{
Kanan Deep $\operatorname{Kaur}^{1}{ }^{*}$, Dr. Vibhuti Gupta ${ }^{2}$
}

\section{ABSTRACT}

The present research examined the impact of personal characteristics on innovative work behaviour of 120 teachers. Using the survey method, participants were asked to give responses on the measures of innovative work behaviour, work engagement, work locus of control, and affect. Pearson's product moment correlation was calculated to see the relationship between work engagement, work locus of control, affect (positive affect \& negative affect), and innovative work behaviour. The effect of confounding variables - grade, age, and experience on innovative work behviour was also observed by calculating a 2x2x3 between subjects ANOVA. The quantitative analysis revealed that positive affect was the strongest predictor of innovative work behaviour followed by internal work locus of control while there was no significant effect of the confounding variables on innovative work behaviour. The study has implications for innovation development and implementation in schools, and developing screening methods for teachers.

Keywords: Innovation Development, Innovative Work Behaviour, Work Engagement, Work Locus Of Control, Affect, Teachers.

Teachers plant the seeds of understanding the world and its rules in their students; they provide their students with not only the knowledge but also the ability to attain and synthesize it. In the fast-paced and rapidly changing society of today, innovation is becoming a key driving factor for sustainability and success. This facet is even more crucial in schools - they play a vital role in the knowledge economy, a fact stressed by different governments (Thurlings, Evers, Vermeulen, 2014), they have to constantly indulge in new ways of imparting valuable information to students, and make efforts to sustain their curiosity and interests. Another reason to stress the

\footnotetext{
${ }^{1}$ Department of Applied Psychology, University of Delhi, South Campus, New Delhi, India

${ }^{2}$ Assistant Professor, Department of Applied Psychology, University of Delhi, South Campus, New Delhi, India *Responding Author

(C) 2016 I K Kaur, V Gupta; licensee IJIP. This is an Open Access Research distributed under the terms of the Creative Commons Attribution License (http://creativecommons.org/licenses/by/2.0), which permits unrestricted use, distribution, and reproduction in any Medium, provided the original work is properly cited.
} 


\section{The Impact of Personal Characteristics on Innovative Work Behaviour: An Exploration into Innovation and Its Determinants amongst Teachers}

requirement of innovative behaviour in education is the increasing demands of our knowledge intensive society on both students and teachers (Brandsford, Derry, Berliner, \& Hammerness, 2005) and introduction of new technologies, ideas, and curriculum changes. Additionally, teachers not only transfer knowledge to students but also impart the students with the skills of gathering knowledge and actively constructing meaning on their own (Thurlings, Evers, Vermeulen, 2014).

A look into innovative work behaviour (IWB) in teachers can thus provide a number of useful insights, regarding - the factors that drive change in schools, how innovative behaviour can be enhanced in schools such that it leads to optimal outcomes, and most importantly how it can contribute to our society at large by enhancing how children accumulate and assimilate knowledge.

In this research we look into the various personal characteristics of teachers that may affect their innovative work behaviour at school. The factors considered in this research are - work engagement, work locus of control (internal/external), affect (positive/ negative), and confounding variables - grade, age, and experience. Messmann and Mulder (2011) set the premise to our research; in their qualitative study of innovative work behaviour in teachers, they used the critical incidents technique, and structured interviews to conclude that motivation and personality of teachers are important triggers for innovative work behaviour. They further suggested that future research must probe in this direction to explore how the characteristics of teachers act as antecedents to their innovative work behaviour.

Innovative behaviour has been defined differently by different authors; in a comprehensive definition Janssen (2000) defines innovative work behaviour as the intentional creation, introduction and application of new ideas within a work role, group or organization, in order to benefit role performance, the group or the organization. He further suggested that innovative work behaviour consists of idea generation, idea promotion, and idea realization.

Innovation research has taken two forms in the past - the macro approach and the micro approach. The macro approach considered the organization as a single unit of analysis and innovations here were seen as closely linked to economic growth and organizational success, leading to more emphasis on market dynamics, innovation diffusion and management (Messmann \& Maulder, 2011) than individual contribution, social aspects of innovation process were still taken into account (Von Hippel, 1995)

The recent micro approaches to innovations imply the important role of the individual as an innovator (Anderson, De Dreu, \& Nijstad, 2004, Messmann and Maulder, 2011). Innovations are being viewed as more than just an important part of the organizational functioning, but also as

(c) The International Journal of Indian Psychology, ISSN 2348-5396 (e)| ISSN: 2349-3429 (p) | 159 


\section{The Impact of Personal Characteristics on Innovative Work Behaviour: An Exploration into Innovation and Its Determinants amongst Teachers}

beneficial to employees in terms of meeting job demands, communication, and job satisfaction (Janssen, 2000). Innovations are now seen as intentional introduction of new ideas and their subsequent utilization and applications. This research explores innovation in the same context.

Messmann and Maulder (2012) propose that innovative work behaviour is a multi-dimensional construct and that different dimensions of innovative work behaviour are linked to different stages of the innovative process. This idea has its roots in Kater's (1988) ideas. The process of innovation begins at Opportunity Exploration which encompasses recognition of problem areas that hold potential for development, next is the Idea Generation stage where novel ideas take birth followed by Idea Promotion which aims at gaining the group's approval, and necessary resources for implementation. Lastly, Reflection which is present in all stages to keep a check on the ideas and their development. Innovative work behaviour thus is a dynamic, multi-stage process which is context bound.

We assessed innovative work behaviour using the self-report questionnaire developed by Messmann and Mulder (2012) which provides a context bound measurement of innovative work behaviour in teachers. Here, innovative work behaviour is seen as a set of tasks/work activities carried out by individuals in their job roles.

The other constructs looked into were the construct of work engagement, defined as a positive, fulfilling, affective-motivational state of work-related well-being that can be seen as the opposite to job burnout (Bakker, Schaufeli, Leiter \& Taris 2008), work locus of control-based in Rotter's seminal work describes how the behaviour of people is affected by their belief in the origin of success or reward; and if they depend on forces within themselves-internal locus of control; or forces such as luck or destiny- external locus of control (Rotter, 1966). Lastly, Affect was assessed based on the models by Tellegen, 1985; Watson \& Tellegen, (1985) who describes high positive affect with key words such as 'active, excited' while low positive affect as 'drowsy, dull'. High negative affect can range from 'distressed, fearful' to 'calm and relaxed'.

Researches done in the past, although sparse, provide meaningful insights into the problem discussed in this research.

Messmann and Maulder (2011, 2012) in their extensive research with vocational teachers provide a sound basis to the current research. Numerous findings are noteworthy - In 2011, through their qualitative assessment of the construct and its dimensions, the authors established that teachers report self-actualization, motivation, curiosity, and openness as the primary personal characteristics that act as triggers for innovative work behaviour. In 2012, their review indicated that perceived self-efficacy, impact, and intrinsic motivation were identified mediating factors for innovative work behaviour. Lastly, their 2012 research states that future research must

(C) The International Journal of Indian Psychology, ISSN 2348-5396 (e) | ISSN: 2349-3429 (p) | 160 


\section{The Impact of Personal Characteristics on Innovative Work Behaviour: An Exploration into Innovation and Its Determinants amongst Teachers}

look beyond vocational teaching to explore innovation development in teachers in the general education system; they also suggest a look at this construct quantitatively to establish a substantiated understanding.

In other research; Binnewies and Gromer (2012) in a sample of 89 teachers in Germany looked into Creative requirement, Job control, Co-worker and supervisor support for creativity, Personal initiative, Idea generation, Idea promotion, and Idea implementation. They concluded that idea generation was positively influenced by job control and creative requirements: teachers should feel they have control over their jobs, and at the same time, they need to be challenged to be creative. Messmann \& Maulder (2014) concluded that engagement in all innovative behaviours can be enhanced by creating an intrinsically motivating work environment that contains collaborative work structures, a safe space for errors and reflection, and sensitivity for contextspecific problems and needs. Messmann and Mulder (2011), and Horng, Hong, Chanlin, Chang \& Chu (2005) found a positive relationship between intrinsic motivation and innovative behaviour. Tomic and Brouwer (1999), Ross and Bruce (2007), and Messmann and Mulder (2011) suggested that positive communication with others affected innovative behaviour. Tomic and Brouwer (1999) gathered data from 146 secondary education teachers on open ended questionnaires analysed through mixed methods, specifically indicated that talking to colleagues promoted idea generation.

Thus, it was hypothesised that - There will be a positive correlation between innovative work behaviour and work engagement (Hypothesis 1); There will be a positive correlation between innovative work behaviour and positive affect (Hypothesis 2); There will be no/negative correlation between innovative work behaviour and negative affect (Hypothesis 3)

Further, Curiosity has been linked to Innovative work behaviour as a contributor to the first step in an innovation process, it facilitates opportunity exploration, this link has been supported by Messmann and Mulder (2011) where they found curiosity to be an important factor in teachers in relation to their active involvement in innovation development and in overcoming difficulties encountered in the innovation process. Curiosity was also found to be important in a study by Horng et al. (2005) where through interviews and observations, it was concluded that teachers who were curious demonstrated more creative teaching behaviour. Borasi and Finnigan (2010) found creative problem solving (finding ways to work around problems and identifying alternative strategies or approaches), capitalizing on a crisis, and dysfunction important for innovative behaviour. Successful teachers took advantage of the crisis or disorganization in their institution as a way of moving their own entrepreneurial initiatives forward. Self-efficacy has often been studied in the context of schools, more specifically, in the context of educational improvements and teacher learning. Research points out that the higher the self-efficacy of teachers, the more they are open to new ideas and the more willing they are to experiment with

(c) The International Journal of Indian Psychology, ISSN 2348-5396 (e)| ISSN: 2349-3429 (p) | 161 


\section{The Impact of Personal Characteristics on Innovative Work Behaviour: An Exploration into Innovation and Its Determinants amongst Teachers}

new methods to better meet the needs of their students. Self-efficacy has been linked to Innovative work behaviour by various other researchers (Horng et al., 2005; Mueller et al., 2008; Runhaar, 2008; Stylianidou et al., 2005). Runhaar (2008) found a positive correlation between teacher self-efficacy and their innovative behaviour in vocational education. According to Yu, Wu, Chen \& Lin (2007) in a quantitative research involving 1493 employees (521 of them were elementary school teachers) looked into adult playfulness, job satisfaction, organizational playfulness climate, job performance and innovative work behaviour. They reported that adult playfulness also had a positive effect on innovative behaviour. Messman and Mulder (2011) also found that self-actualization was a factor that triggered innovative work behaviour. Aiming to improve work processes and developing new things was also important for innovative behaviour. Thus, two hypotheses were formed further - There will be a positive correlation between innovative work behaviour and internal work locus of control (Hypothesis 4); and there will be no/negative correlation between innovative work behaviour and external work locus of control (Hypothesis 5)

We identified a research gap in past research there was a need to look into the influence of school context and differences within the school system, and how they affect innovative work behaviour in teachers (Thurlings, Evers \& Vermeulen, 2014). Messman and Maulder (2010) through correlation analysis of innovative work behaviour in vocational teachers showed that age and work experience correlated positively with innovative work behaviour. While age (inside the classroom; $\mathrm{r}=.43, \mathrm{p}<.01$ ) and work experience correlated positively with innovative work behaviour (inside the classroom; $\mathrm{r}=.34, \mathrm{p}<.05$ and outside; $\mathrm{r}=.30, \mathrm{p}<.05$ ). In providing further insight into these findings the authors proposed that with age and experience vocational teachers had better understanding of the needs of their students and characteristics of their future job options. This effect was noteworthy and thus was measured in this research to ascertain if results varied for academic teachers in schools on various grade levels, age groups and years of experience.

In the Indian educational context, changes in approaches to teaching are being introduced by means of information and computer technology, the system is introducing changes to emphasize the importance of practical learning. Recent changes in assessment and evaluation implemented by the Central Board of School Education have taken a step forward in this direction by introducing new methods of evaluation to assess students on various aspects. These changes demand teachers to implement new projects and materials in their assessment to enable a holistic assessment of their students. This approach is in tandem with how research on innovation in schools has been carried out in the past, research focuses on systematic innovations which involve large scale reforms of projects that are based on externally designed innovations (Messmann and Maulder, 2011).Although important for the development of educational practices at large, this approach fails to look into the local contexts that influence innovative 
The Impact of Personal Characteristics on Innovative Work Behaviour: An Exploration into Innovation and Its Determinants amongst Teachers

behaviour. System-wide innovations view teachers as merely users of innovation rather than being the innovators themselves. This research thus attempts to fulfil the need to look into the personal characteristics within teachers that influence innovative practices for both system-wide innovations and individually initiated ones.

\section{METHOD}

The study was preceded by a pilot study to test the comprehension of the self-report questionnaire of innovative work behaviour developed by Messmann and Mulder (2012). The sample included 5 teachers who volunteered as participants. The sample was based in Delhi, India and it was made sure that the sample was collected from varied schools and grade levels. As a result an introductory text was added to set the context and the statements of the original measure of innovative work behaviour were modified to enable better understanding of the statements.

\section{Participants}

Data was collected from Patiala, Punjab. The sample for this study included 120 participants achieved through convenient sampling. The final sample included 120 participants who ranged in grade - primary, secondary, and higher secondary; age from $21-57$ years (Mean age $=39.08$ years, $\mathrm{SD}=7.69$ years), and in experience from 01-34 years (Mean experience $=12.28$ years, $\mathrm{SD}=6.98$ years).Those teachers were considered who were presently teaching in a school (I.C.S.E/C.B.S.E). The gender of the sample was not controlled due to the skewed gender distribution of teachers in the region with more female teachers to male teachers.

\section{Materials used}

The sample of 120 teachers completed 4 instruments, namely - Innovative Work Behaviour Scale by Messmann \& Maulder, 2012; Utrecht Work Engagement Scale (UWES; Schaufeli, Salanova, González-Romá \& Bakker, 2002a); the Work Locus of Control - 8 (Spector, 1988); Positive and Negative Affect Schedule Short Form (I-PANAS-SF), a short 10-item version (Thompson, 2007).

\section{Innovative Work Behaviour}

A 20 item self-report questionnaire developed by Messmann and Maulder (2012) was used to measure Innovative Work Behaviour (IWB). Each item is rated on a 6-point likert scale ranging from 1(does not apply) to 6 (fully applies) to report the extent to which each work activity adequately describes their work behaviour. The language of the items was modified to enable better understanding; this modification was tested in a pilot study prior to formal data collection. An introductory text was provided which was modified from its original version to ensure better comprehension and establishment of a context.

(c) The International Journal of Indian Psychology, ISSN 2348-5396 (e)| ISSN: 2349-3429 (p) | 163 


\section{The Impact of Personal Characteristics on Innovative Work Behaviour: An Exploration into Innovation and Its Determinants amongst Teachers}

Evidence for construct validity for the measure was reported in Messmann and Mulder (2012) and was obtained through two studies. In both of these studies, exploratory factor analysis was used to research and develop a measurement model of IWB in combination with theoretical considerations (Messmann and Mulder 2012).The evidence for criterion validity was obtained through relations between the dimensions of IWB and individual and criterion variables. Cronbach's alpha was achieved for the various dimensions was satisfactory - Opportunity Exploration $(\alpha=.72 / .81)$, Idea Generation $(\alpha=.82 / .87)$, Idea Promotion $(\alpha=.88 / 86)$ and Reflection $(\alpha=.75 / .81)$

\section{Work Engagement}

Work Engagement was assessed using the Utrecht Work Engagement Scale (UWES; Schaufeli, Salanova, González-Romá \& Bakker, 2002a). The construct consists of 3 dimensions - Vigour, Absorption and Dedication. The measure has strong inter-correlation where the three dimensions are closely related. The correlations between the dimensions of work engagement are more than .65. There is strong internal consistency where Cronbach's $\alpha$ for all case values and are at .70 or exceed it. For the different dimensions of the construct, Cronbach's $\alpha$ values range from .80 and .90 (Schaufeli \& Bakker, 2003). The measure also shows strong reliability over time. The two year stability coefficients obtained for the three dimensions are strong; vigour (.30), dedication (.36) and absorption (.46) (Schaufeli \& Bakker, 2003).

\section{Work Locus of Control}

To measure Locus of Control a domain specific construct - Work Locus of Control - 8 (WLOC), a short version was used. The measure contains 8 items with 6-point likert rating scale where the responses range from 1 (disagree very much) to 6 (agree very much). The scoring was modified for ease of analysis - separate scores for each dimension - Internal Locus of Control and External Locus of Control were recorded. Coefficient alpha was .81 for the 8 -item version $(n=1170)$. The norms for this construct in India state a mean score of 46 which indicates a external work locus of control (Spector, 1988)

\section{Affect}

The International Positive and Negative Affect Schedule Short Form (I-PANAS-SF), a short 10item version by Thompson, 2007 of the PANAS of Watson, Clark, \& Tellegen (1988) was used to measure affect. PANAS measures two dimensions of mood - Positive Affect and Negative Affect. The measure consists of 10 items which are rated on a 5 point interval measure ranging from 'Never' to 'Always'. The I-PANAS-SF PA subscale had a satisfactory correlation with the full PANAS PA subscale of .65 $(\mathrm{p}<.01)$, and the respective NA subscales had a correlation of $.59(\mathrm{p}<.01)$ suggesting a satisfactory comparison with the full form. The test-retest coefficient of reliability for both the PA and NA is the same, at .84 ( $<<.01)$, suggesting acceptable temporal stability.

(C) The International Journal of Indian Psychology, ISSN 2348-5396 (e)| ISSN: 2349-3429 (p) | 164 
The Impact of Personal Characteristics on Innovative Work Behaviour: An Exploration into Innovation and Its Determinants amongst Teachers

\section{Procedure}

The data gathered was analysed quantitatively. Correlations were calculated for all the variables and subsequently multiple regression was computed for significant correlates of innovative work behaviour using step-wise regression method. To assess the effect of confounding variables on innovative work behaviour a 2X2X3 factorial design with a between subjects comparison of Age (35 and below, and above 35), Experience (10 years and below, and above 10 years) and Grade (Primary, Secondary and Higher Secondary was taken.

\section{RESULTS}

Table 1: Pearson product moment correlation coefficients between the study variables for the total sample $(N=120)$

\begin{tabular}{|l|l|l|l|l|l|l|}
\hline & IWB & WE & Internal WLOC & External WLOC & PA & NA \\
\hline IWB & - & & & & & \\
\hline WE & $0.370^{* *}$ & - & & & & \\
\hline Internal WLOC & $0.317^{* *}$ & $0.346^{* *}$ & - & & & \\
\hline External WLOC & 0.017 & -0.087 & -0.093 & - & & \\
\hline PA & $0.389 * *$ & $0.493^{* *}$ & $0.182^{*}$ & -0.068 & - & \\
\hline NA & -0.065 & -0.068 & -0.1 & 0.117 & $-0.235^{* *}$ & - \\
\hline
\end{tabular}

** Correlation is significant at less than 0.01 level (2-tailed) * Correlation is significant at less than 0.05 level (2-tailed)

Results indicated a positive correlation between innovative work behaviour (IWB) and work engagement (WE) $(\mathrm{r}=.37, \mathrm{p}<.01)$, between innovative work behaviour and internal work locus of control (IWLOC) $(\mathrm{r}=.32, \mathrm{p}<.01)$, and between innovative work behaviour and Positive Affect (PA) $(\mathrm{r}=.39, \mathrm{p}<.01)$. The correlation coefficients have been reported in table 1 . Thus, hypotheses 1,2 , and 4 were accepted.

Furthermore, correlation analysis indicated an insignificant(but negative) correlation between innovative work behaviour and negative affect, thus hypothesis 3 was accepted. An insignificant correlation was obtained between innovative work behaviour and external work locus of control, thus, hypothesis 5 was accepted.

A regression analysis was done using the step-wise method where, the $\mathrm{R}$ and $\mathrm{R}$ square values were obtained (table 2). The beta coefficients, $t$ value and the significance value can be seen in table 3 .

(c) The International Journal of Indian Psychology, ISSN 2348-5396 (e)| ISSN: 2349-3429 (p) | 165 
The Impact of Personal Characteristics on Innovative Work Behaviour: An Exploration into Innovation and Its Determinants amongst Teachers

Table 2: $R^{2}$ and Adjusted $R^{2}$ values for predictor variables (positive affect, internal work locus of control) as predictors for the criterion variable (innovative work behaviour)

\begin{tabular}{|c|c|c|c|c|}
\hline Criterion Variable & Predictor Variable & $\mathbf{R}$ & $\begin{array}{l}\mathbf{R} \\
\text { Square }\end{array}$ & $\begin{array}{ll}\text { Adjusted } & \mathbf{R} \\
\text { Square } & \end{array}$ \\
\hline $\begin{array}{l}\text { Innovative } \quad \text { work } \\
\text { behaviour }\end{array}$ & Positive Affect & 0.389 & 0.152 & 0.144 \\
\hline & $\begin{array}{lll}\text { Internal Locus of } \\
\text { Control }\end{array}$ & 0.463 & 0.214 & 0.201 \\
\hline
\end{tabular}

Table 3: Beta coefficients, $t$-values and significance values for multiple regression

\begin{tabular}{|l|l|l|l|l|l|l|}
\hline \multirow{2}{*}{$\begin{array}{l}\text { Mod } \\
\text { el }\end{array}$} & & \multicolumn{2}{|l|}{$\begin{array}{l}\text { Unstandardized } \\
\text { coefficients }\end{array}$} & $\begin{array}{l}\text { Standardized } \\
\text { coefficients }\end{array}$ & t & Sig. \\
\hline & & B & $\begin{array}{l}\text { Std. } \\
\text { Error }\end{array}$ & Beta & & \\
\hline & & & & & & \\
\hline 1 & Positive Affect & 1.958 & 0.43 & 0.389 & 4.591 & .000 \\
\hline 2 & Positive Affect & 1.724 & 0.42 & 0.343 & 4.114 & .000 \\
\hline & $\begin{array}{l}\text { Internal Work Locus of } \\
\text { Control }\end{array}$ & 0.754 & 0.25 & 0.255 & 3.057 & 0.003 \\
\hline
\end{tabular}

Dependent Variable -innovative work behaviour

Using the independent variables - positive affect, work locus of control and work engagement to predict innovative work behaviour, yielded a coefficient of multiple regression (R) of .389 and an adjusted multiple regression square $\left(\mathrm{R}^{2}\right)$ of .144 for positive affect, indicating that $14.4 \%$ of the variance caused in innovative work behaviour is accounted for by positive affect (Table 2). Since the step-wise method was used for multiple regression, the next variable that caused variance in innovative work behaviour was internal work locus of control. Together both these variables yielded a coefficient of multiple regression (R) of .463 and an adjusted multiple regression square $\left(\mathrm{R}^{2}\right)$ of .201; thus internal work locus of control caused a variance of $5.7 \%$ in innovative work behaviour among teachers.

When Innovative work behaviour was predicted it was found that positive affect (Beta coefficient $=0.389, \mathrm{p}<.01$ ), and internal work locus of control (Beta coefficient $=0.255, \mathrm{p}<$ .01 ) were significant predictors (Table 3).

(c) The International Journal of Indian Psychology, ISSN 2348-5396 (e)| ISSN: 2349-3429 (p) | 166 
The Impact of Personal Characteristics on Innovative Work Behaviour: An Exploration into Innovation and Its Determinants amongst Teachers

Table 4: Two-Way ANOVA results for the effect of confounding variables (Age, Experience and Grade) on Innovative Work Behaviour

\begin{tabular}{|l|l|l|l|l|l|}
\hline Source & $\begin{array}{l}\text { Type III } \\
\text { Sum of } \\
\text { Squares }\end{array}$ & Df & $\begin{array}{l}\text { Mean } \\
\text { Square }\end{array}$ & F & Sig. \\
\hline Age & 59.305 & 1 & 59.305 & 0.57 & 0.452 \\
\hline Experience & 80.886 & 1 & 80.886 & 0.777 & 0.38 \\
\hline Grade & 33.862 & 2 & 16.931 & 0.163 & 0.85 \\
\hline Age * Experience & 194.516 & 1 & 194.516 & 1.869 & 0.174 \\
\hline Age * Grade & 106.061 & 2 & 53.03 & 0.51 & 0.602 \\
\hline Experience * Grade & 15.838 & 2 & 7.919 & 0.076 & 0.927 \\
\hline Age * Experience * Grade & 52.699 & 2 & 26.35 & 0.253 & 0.777 \\
\hline Error & 11238.979 & 108 & 104.065 & & \\
\hline
\end{tabular}

Further, the result of the between subjects ANOVA indicated that there was no significant difference between the two age levels; younger and older $[\mathrm{F}(1,108)=.0 .57, \mathrm{p}=.452]$, two levels of experience; less experienced and more experienced $[\mathrm{F}(1,108)=.0 .77, \mathrm{p}=.38]$ and the three grade levels with respect to innovative work behaviour $[\mathrm{F}(2,108)=.0 .16, \mathrm{p}=.85]$. There was also no interaction effect seen between age and experience for this variable $[\mathrm{F}(1,108)=$ $.407, \mathrm{p}=.667]$. The results were similar for the interaction between age and grade $[\mathrm{F}(2,108)=$ $.0 .51, \mathrm{p}=.602]$ and between experience and grade $[\mathrm{F}(2,108)=.076, \mathrm{p}=.927]$. Also, the interaction effect of all the three variables i.e. age, grade and experience was insignificant on innovative work behaviour $[\mathrm{F}(2,108)=.253, \mathrm{p}=.777)$.

\section{DISCUSSION}

This research aimed at looking into the relationship between innovative work behaviour and work engagement, work locus of control (internal/external), and affect (positive/negative) in teachers. We found that while work engagement, internal work locus of control, and positive affect correlated positively with the construct of innovative work behaviour (as hypothesized); positive affect and internal locus of control were the significant predictors. In accordance with the hypotheses it was also seen that there is a no significant correlation (though negative) between negative affect and innovative work behaviour and an insignificant correlation between external work locus of control and innovative work behaviour. Further, the confounding variables - grade, age, and experience had no significant effect on innovative work behaviour. The results achieved in this study help us gain a better understanding of the construct of innovative work behaviour; they are similar to the past research done in the same context. From

(c) The International Journal of Indian Psychology, ISSN 2348-5396 (e)| ISSN: 2349-3429 (p) | 167 


\section{The Impact of Personal Characteristics on Innovative Work Behaviour: An Exploration into Innovation and Its Determinants amongst Teachers}

previous research we know that employees who are engaged tend to report high levels of energy, zeal towards their work and a sense of being completely engrossed in work such that a track of time cannot be maintained while they are working (Bakker, Schaufeli, Leiter \& Taris, 2008). Research indicates a positive coping style, self-efficacy, self-esteem (based in the organization), optimism are related to work engagement (Bakker \& Demerouti, 2008). Further indications were that when faced with demands from a broad array of contexts, engaged individuals believed that they could successfully achieve those demands. Similarly, individuals with an internal locus of control are more likely to consider outcomes to be dependent upon one's effort and skill, while individuals with an external locus tend to attribute outcomes to chance and often constructs like destiny, fate or luck (Rotter, 1966). Research has established that the construct of locus of control is based on a cause and effect relationship where behaviour being displayed currently is affected by what one expects the future will hold. In terms of affect, research has shown while positive affect contains the feelings of enthusiasm, being active and alert, a high positive affectivity can be characterized as a state of being high on energy, full of concentration and experiencing pleasurable engagement where as a low positive affectivity can be categorized as being dull and lethargic. On the contrary, negative affectivity is a dimension seen as a state of un-pleasurable engagement which may include within itself an array of aversive mood states. A low negative affect would indicate a state of calmness and tranquility. Thus, it can be deduced that aspects of work engagement, internal locus of control and positive affect are intricately related to each other and a cumulative contribution, of these three will lead to positive work outcomes.

The current research indicated that positive affect and internal work locus of control were the significant predictors of innovative work behaviour in teachers. These findings are in line with and are further explained by a few researches in the past; Judge et al, 2008; studied positive affect which was experimentally induced, had cognitive consequences that seemed to improve performance on cognitive tasks. Individuals in a positive mood generated more cognitive associations and were more flexible in terms of how they thought about problems, thus making them more effective at creative problem solving tasks. Tomic and Brouwer (1999), Ross and Bruce (2007), and Messmann and Mulder (2011) also stated that positive communication played an important role in the idea generation stage of innovative work behaviour.

Similarly, locus of control has an influence on job performance and career success via motivational processes. Research by Wang et al. (2010) lends an explanation to our findings and states that individuals with an internal locus of control set themselves up for more challenging goals and are more likely to pursue them even when things get difficult. Thus, showing a superior performance as compared to individuals with an external locus of control; it is also seen that internals are better at social situations - they show consideration of others and better interpersonal skills. Finally, internals cope with problems proactively when faced with difficult

(C) The International Journal of Indian Psychology, ISSN 2348-5396 (e) | ISSN: 2349-3429 (p) | 168 
situations. They engage in problem focused coping and seek instrumental social support. Thus internal locus of control has a significant impact on the four aspects of innovative work behaviour - opportunity exploration, idea generation, idea implementation and reflection as measured in this research. Research further states that job control and creative requirements positively influence idea generation; while another research by Messmann \& Maulder(2014) suggests creating a work environment that facilitates intrinsic motivation, collaborative work structures, a room for errors and reflection to enhance innovative behaviour.

Our results are further supported by Messmann and Mulder (2011), and Horng et al (2005) who found a positive relationship between intrinsic motivation and innovative behaviour. Selfefficacy is an important factor that is at play here. It has often been studied in the context of schools, more specifically, in the context of educational improvements and teacher learning. Research points out that the higher the self-efficacy of teachers, the more they are open to new ideas and the more willing they are to experiment with new methods to better meet the needs of their students. Self-efficacy has been linked to innovative work behaviour by various other researches (Horng et al., 2005; Mueller et al., 2008; Runhaar, 2008; Stylianidou et al., 2005). Runhaar (2008) found a positive correlation between teacher self-efficacy and their innovative behaviour in vocational education.

Finally, unlike for vocational teachers (Messman and Maulder, 2010) grade, age, and experience did not seem to have an influence on innovative work behaviour in teachers. It can be possibly assumed that in the Indian Education System there seem to be a lack in differentiation of the job role and expectations from a teacher to create an impact on their engagement in innovations. Thus, personal characteristics seem to have a bigger impact than contextual factors rooted in the system in teachers and their innovative work behaviour.

\section{CONCLUSION}

This research indicated that there is a positive correlation between innovative work behaviour and positive affect, innovative work behaviour and internal work locus of control and innovative work behaviour and work engagement where positive affect and internal work locus of control were the strongest predictors of innovative work behaviour respectively. On the other hand there was an insignificant correlation between negative affect and innovative work behaviour and an insignificant correlation was found between external locus of control and innovative work behaviour. Lastly, the confounding variables - grade, age, and experience had no effect on innovative work behaviour in teachers.

Research on innovative work behaviour in teachers could continue in several directions. Firstly, one of the limitations of this research is a lack of depth in terms of qualitative data. Future research must take into account a deeper probe through a mixed method design. Secondly, the

(c) The International Journal of Indian Psychology, ISSN 2348-5396 (e)| ISSN: 2349-3429 (p) | 169 

and Its Determinants amongst Teachers

impact of school and its structural components such as the level of experience a teacher has, their grade and their age may have an impact on how they engage in innovative work behaviour, there is scope to take this research further and see the effect of work context on the variables. Thirdly, future research can capture nuances of the effect of work context by looking into the government sector in comparison to private sector teaching in India; this can also help in deducing the factors that drive innovation in both. Finally, research in the future can attempt to map these traits over a larger sample to provide a more inclusive assessment of innovation in teachers.

Nonetheless this research has some meaningful implications for education in India - The insight into the predictor variables of Innovative work behaviour in teachers can assist in designing of screening methods for recruitment of teachers in schools by measuring their work locus of control and affect. It can also help predict their contribution to innovation processes at school. Schools can also try to create a conducive environment for teachers which facilitate positive affect and allows room for initiative to provide breeding ground for innovations.

In conclusion, the research indicates that positive affect and internal work locus of control are the significant predictors of innovative work behaviour in teachers, thus it is important that teachers should be provided with an environment which allows for autonomy in their job role to enhance their performance. Also, activities that promote positive affect can be introduced in the school context to keep teachers motivated and engaged to initiate ground-breaking innovations.

\section{REFERENCES}

Amabile, T. M. (1988). A model of creativity and innovation in organizations. In B. M. Staw \& L. L. Cummings (Eds.), Research in organizational behaviour (pp. 187-209). Greenwich, CT: JAI

Baas,M., De Dreu, C.K.W., and Nijstad, B.A. (2008). A Meta-Analysis of 25 Years of MoodCreativity Research: Hedonic Tone, Activation, or Regulatory Focus? 'Psychological Bulletin.' 134 (6), pp.779-806

Bakker, A.B.\& Demerouti, E. (2008). Towards a model of work engagement. Career Development International, Vol. 13 No. 3, pp. 209-223. Emerald Group Publishing Limited 1362-0436. DOI 10.1108/13620430810870476

Bakker, A.B., Schaufeli, W.B., Leiter, M.P. \&Taris, T.W. (2008). Work engagement: An emerging concept in occupational Health Psychology. Work \&Stress, Vol.22, No. 3, 187200.

Binnewies, C., \& Gromer, M. (2012). Creativity and innovation at work: The role of work characteristics and personal initiative. Psicothema, 24, 100-105. Retrieved from http://www.psicothema.com/PDF/3985.pdf 

and Its Determinants amongst Teachers

Birdi, K., Leach, D. \& Magadley, W. (2014). The Relationship of Individual Capabilities and Environmental Support with Different Facets of Designers' Innovative Behavior. Journal of Product Innovation Management. Wiley Periodicals, Inc.

Carmeli, A., Meitar, R., \& Weisberg, J. (2006). Self-leadership skills and innovative behaviour at work. International Journal of Manpower, 27, 75-90. doi:10.1108/01437720610652853

De Jong, J.P.J, Den Hartog, D.N (2008). Innovative work behaviour: Measurement and Validation. Scientific Analysis of Entrepreneurship and SMEs Initiative (SCALES)

George, J. M. and Zhou, J. (2002). Understanding when bad moods foster creativity and good ones don't: The role of context and clarity of feelings. Journal of Applied Psychology. 87, pp.687-697

George, J. M. and Zhou, J. (2007). Dual tuning in a supportive context: Joint contributions of positive mood, negative mood, and supervisory behaviours to employee creativity. Academy of Management Journal. 50 (3), pp.605-622.

Hakanen, J.J., Bakker A.B, Schaufeli, W.B. (2006). Burnout and work engagement among teachers. Journal of School Psychology 43495 - 513

Janssen, O. (2003) Innovative behaviour and job involvement at the price of conflict and less satisfactory relations with co-workers. Journal of Occupational and Organizational Psychology Volume 76, Issue 3, pages 347-364, September 2003

Janssen, O. (2005). The joint impact of perceived influence and supervisor supportiveness on employee innovative behaviour. Journal of Occupational and Organizational Psychology. Volume 78, Issue 4, pages 573-579

Judge, T.A., \& Kammeyer-Mueller, J.D. (2008). Affect, satisfaction, and performance. In Neal Ashkanasy \& C. Cooper (Eds.), Research Companion to Emotion in Organizations. Thousand Oaks, CA: Sage.

Kanter, R.M. (1988) When a Thousand Flowers Bloom: Structural, Collective, and Social Conditions for Innovation in Organizations. Research in Organizational Behaviour, Vol.10, pages 169-211. JAI Press Inc.

Messmann, G., \& Mulder, R. H. (2011). Innovative work behaviour in vocational colleges: Understanding how and why innovations are developed. Vocations and Learning, 4(1), $63-$

Messmann, G., \& Mulder, R. H. (2012). Development of a measurement instrument for innovative work behaviour as a dynamic and context-bound construct. Human ResourceDevelopment International, 15(1), 43-59.

Messmann, G., Mulder, R. H., \& Gruber, H. (2010). Relations between vocational teachers'characteristics of professionalism and their innovative work behaviour. Empirical Research in Vocational Education and Training, 2(1), 21-40.

Ramamoorthy, N., Flood, P.C., Slattery, T. and Sardessai, R. (2005). Determinants of Innovative Work Behaviour: Development and Test of an Integrated Model. Creativity and Innovation Management. Volume 14, Issue 2, pages 142-150. 
The Impact of Personal Characteristics on Innovative Work Behaviour: An Exploration into Innovation and Its Determinants amongst Teachers

Rotter, J.B. (1990). Internal Versus External Control of Reinforcement: A Case History of a Variable. American Psychologist, Vol. 45, No. 4, 489—493.

Runhaar, P. (2008). Promoting teachers' professional development (Unpublished doctoral dissertation). Universiteit Twente, Enschede, Netherlands.

Russell, J.A. \& Carroll, J.M. (1999).On the Bipolarity of Positive and Negative Affect. Psychological Bulletin. Vol. 125, No. 1,3-30

Sazandrishvili, N. (2009) Contextual and Personal Antecedents of Innovative Behaviour, Mediating Effect of Learning Goal Orientation on the Relationship between Job Autonomy and Innovative Behaviour [Unpublished Dissertation]. University of Twente.

Schaufeli, W. B., \& Bakker, A. B. (2003). Test manual for the Utrecht Work Engagement Scale. Unpublished manuscript, Utrecht University, the Netherlands. Retrieved from http://www.schaufeli.com

Selart, M. (2005) Understanding the role of locus of control in consultative decision-making: a case study Management Decision Vol. 43 No. 3, 2005 pp. 397-412 q. Emerald Group Publishing Limited. Norway.

Singh, G. (2014) Emerging Trends and Innovations in Teacher Education. Indian Journal for Applied Research. Volume: 4, Issue: 5

Spector, P.E., Cooper, C.L., Sanchez, J.I., O’Driscoll, Sparks, K (2002). Locus of Control and Well-Being at Work: How Generalizable are Western Findings? Academy of Management Journal, Vol. 45. No. 2, 453-466.

Thurlings, M., Evers, A.T., Vermeulen, M. (2014): Toward a Model of Explaining Teachers' Innovative Behavior: A Literature Review. Review of Educational Research

Wang, Q; Bowling, N.A.\& Eschleman, K.J. (2010) Meta-Analytic Examination of Work and General Locus of Control. Journal of Applied Psychology, Vol. 95, No. 4. American Psychological Association.

Zhou, J. and George, J.M. (2003). Awakening employee creativity: The role of leader emotional intelligence. 'Leadership Quarterly.' 14, pp.545-568

How to cite this article: K Kaur, V Gupta (2016), The Impact of Personal Characteristics on Innovative Work Behaviour: An Exploration into Innovation and Its Determinants amongst Teachers, International Journal of Indian Psychology, Volume 3, Issue 3, No. 11, DIP: 18.01.207/20160303, ISBN: 978-1-365-21307-6

(c) The International Journal of Indian Psychology, ISSN 2348-5396 (e)| ISSN: 2349-3429 (p) | 172 